\title{
A LITERATURE REVIEW OF ONLINE TRUST IN BUSINESS TO CONSUMER E-COMMERCE TRANSATIONS, 2001-2006
}

\author{
Shan-Yan Huang, National Dong Hwa University, Taiwan, jie18.roye28@msa.hinet.net \\ Ci-Rong Li, National Dong Hwa University, Taiwan, d9532001@em95.ndhu.edu.tw \\ Chen-Ju Lin, National Dong Hwa University, Taiwan, jzlin0684@gmail.com
}

\begin{abstract}
The purpose of this research is to examine previous literatures which focus on trust in Business to Consumer (B2C) of e-commerce transactions between 2001 and 2006. All selected papers are analyzed through a conceptual framework to recognize the context and nature of trust. The working process includes three primary phases: selecting and focusing phase, analyzing phase, and concluding and outcome-converging phase, which enhance the fulfillment of analysis and the accumulation of knowledge in the domain of B2C trust researches. In the future, the research in this area need clearly indicate how proposed models are tested base on theory, and the nature of B2C trust researches must be identified more detailed, additionally, improving the oversimplification of the trust nature. Moreover, the researchers should associate the focal point with comprehensive in the future.
\end{abstract}

Keywords: E-Commerce, Trust, Trust in ECommerce, Literature Review

\section{INTRODUCTION}

Trust is a key factor that determines the success of Business to Consumer (B2C) e-commerce transactions [20]. With the most mature of the Internet technique environment, the concept of trust has been the kernel of the matter when people interactions with e-commerce web portals. Over 4 in 5 users (80\%) say that being able to trust a web site is very important for them in making a decision to interact with that site (Princeton Survey Research Associates, 2002). Issues relating to trust have crucial economic ramifications as the Taiwan online market will grow treble from 2005 to 2009 (Market Intelligence Center, 2005).

Unfortunately, there are 36\% practitioners failed between 2003 and 2005 that inspire trust in the user (Market Intelligence Center, 2005). Internet shopping involves more uncertainty and risk than traditional shopping. In the context of B2C e-commerce transactions, transactions don't involve simultaneous exchange of goods and money regularly where the intended purchase may be from a supplier that is operating in a different country, time zone, currency and legal system. Moreover, consumers are required to share sensitive personal information (such as mailing address, telephone number) and financial information (such as credit card numbers).

The unclear and underdeveloped legal environment increase uncertainty and risk in ecommerce, some institutional mechanisms used in online marketplaces do not enjoy the same legal protection and enforcement provided by governmental agencies in traditional markets. Trust is an especially important factor under conditions of uncertainty and risk. Lack of trust is one of the most frequently cited reasons for consumers not purchasing from Internet shops. Thus, how to reduce the perceived risk of customers is an important issue. Trust helps consumers overcome perceptions of uncertainty and perceived risk and engages in "trustrelated behaviors" with Web-based vendors, such as sharing personal information or making purchases [31].

Understanding the nature of trust is a major issue for both Internet researchers and practitioners since Internet shopping is a relatively new phenomenon with enormous potential. Both economists and sociologists agree that trust is a crucial enabling factor in relations where there is uncertainty, interdependence, and fear of opportunism as is the case in online markets [30]. The purpose of this research is to analyze published B2C trust literature in major IS journal and conference proceedings between 2001 and 2006, to recognize the nature of the trust, and categorize them within the main streams of research theory. This categorization enables us to reflect critically on a number of conceptual concerns and much of the current researches. After reviewing the academic literatures, this research hopes to identify the future research direction in B2C trust.

\section{LITERATURE COLLECTION AND REVIEW METHODOLOGY}

The methodology used in this research included three primary phases: selection and focus phase, analysis phase, and outcomes and convergence phase. Figure 
1 illustrates the main phase and activities of the research method, and that the research procedures are from outside to inside. Firstly, the selection and focus phase gather up defining research scope and identifying the literature publication based on predefined criteria. Secondly, the analysis phase concentrates on recognizing the research theories after reviewing the literature in B2C trust and then classifying these topics in various categories. Thirdly, the outcomes and convergence phase aim at description the research phenomenon for B2C trust based on the classification, and provide the suggestions for future research in the field.

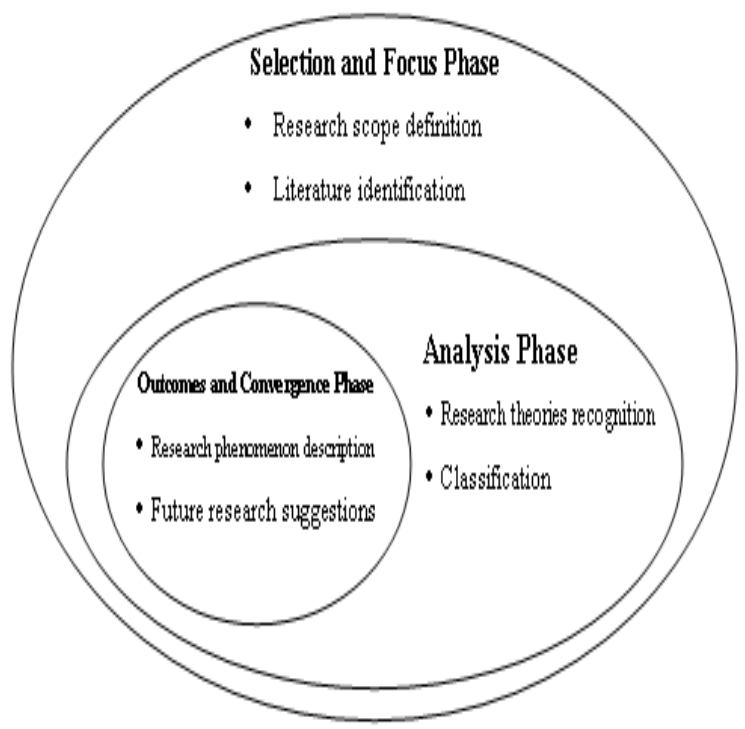

Figure 1. Literature review methodology

\section{Selection and Focus Phase}

The survey scope for B2C trust is defined at this phase. A preliminary literature review of B2C trust researches was carried out by drawing on researches from prominent peer reviewed journals and conference proceedings with high prestige. The published period is between 2000 and 2006 in the IS field. The list of selected IS journals are MIS Quarterly (MISQ), Information System Research (ISR), Journal of Management Information System (JMIS), and Information \& Management (I\&M). Furthermore, several highly recognized journals in management, strategy, marketing and e-commerce research are included in the initial selection criteria, such as Journal of Marketing Research (JMR), Internal Journal of Electronic Commerce (IJEC), International Journal of Information Management (IJIM), Journal of Strategic Information Systems (JSIS), Journal of Business Research (JBR), Academy of Management Review (AMR), Electronic Markets (EM), International Journal of Bank Marketing
(IJBM), Marketing Management (MM), Information Technology and Management (ITM), e-Service Journal (eSJ), International Journal of Service Industry Management (IJSIM), Information Systems and E-Business Management (ISEBM), Psychology \& Marketing (P\&M), and IEEE Transactions on Engineering Management (ITEM). Other publication sources such as Interacting with Computers (IC), ACM SIGMIS Database (ASD), Computers in Human Behavior (CHB), Journal of the American Society for Information Science and Technology (JASIST), Advances in Applied Microeconomics (AAM), books, and conference proceedings are included in this research. In order to research into an issue or a phenomenon, our primary focus was on identifying novel and original researches. The collection and integration of past researches is a purpose which could facilitate future researches. After manually reviewing the abstract of selected articles and screening out the unfitted articles. The final set of the 37 key researches is shown in table 1 . In examining the results of the 37 key researches we noted that B2C trust have four type of the nature between the different researches. The nature of B2C trust researches includes comprehensive, ongoing trust, overall trust and initial trust.

Table 1. Summary of B2C Trust Literatures Nature Type Researches

[3], [7], [36], [21], [27], [11], Overall trust [15], [22], [30], [39], [6], [18], [35], [40], [43], [37], [13], [44], [25], [12], [29], [9]

Initial trust [4], [24], [32], [38], [28], [33], [26], [19]

Ongoing trust

[17], [20], [45], [8]

Compare between

initial and ongoing [16], [23], [46]

trust

The statistical result is shown in Figure 2. The majority (59.5\%) of the researches was focused on overall trust; secondly the research rate of initial trust was $21.6 \%$; thirdly the research rate of ongoing trust was $10.8 \%$. The research rate of comprehensive was only $8.1 \%$. The appearance of researches reflects the trend of the further research efforts in this field. These researches were subsequently analyzed by the theories. This analysis was complemented in light of the current empirical fieldwork. 


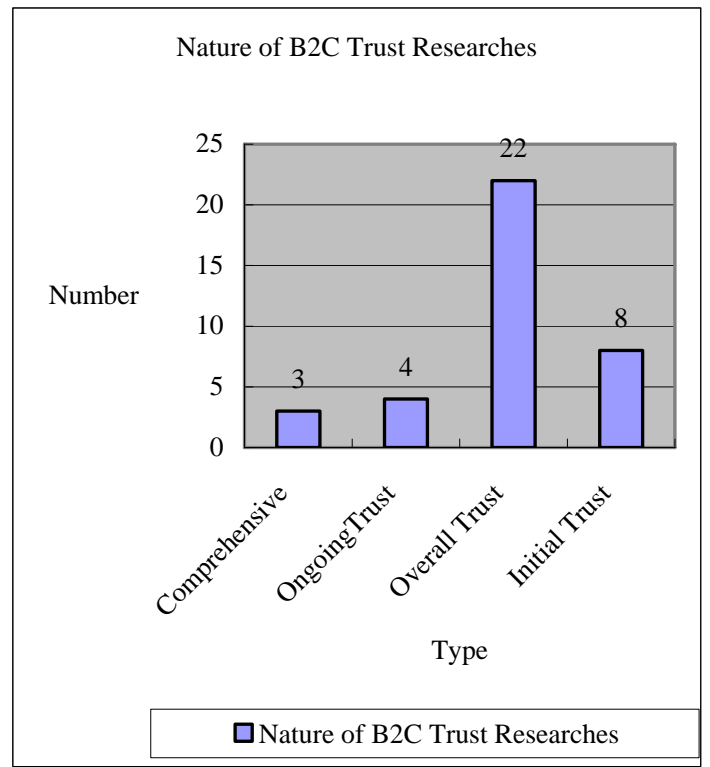

Figure 2. Nature of B2C Trust Researches Statistics

\section{Analysis Phase}

According to the selection phase, several theories are used in B2C trust researches, such as social exchange theory (SET), expectation-confirmation theory (ECT), theory of reasoned action (TRA), theory of planned behavior (TPB), technology acceptance model (TAM). Those trust building models are developed under the base on theories in the environment of e-commerce. Table 2 summarizes these articles in various theories.

Table 2. B2C Trust Research Theories

\section{Theories Researches}

\begin{tabular}{|c|c|}
\hline $\begin{array}{l}\text { Others } \\
\text { or N/A }\end{array}$ & $\begin{array}{l}\text { [3], [7], [36], [27], [11], [4], [15], [24], } \\
\text { [32], [39], [6], [16], [40], [28], [44], } \\
\text { [45], [12], [8] }\end{array}$ \\
\hline SET & [30], [23], [46] \\
\hline$\overline{\text { ECT }}$ & {$[23],[46],[25]$} \\
\hline TRA & $\begin{array}{l}\text { [35], [38], [43], [28], [33], [37], [46], } \\
\text { [29] }\end{array}$ \\
\hline TPB & {$[28],[46]$} \\
\hline TAM & $\begin{array}{l}\text { [21], [22], [17], [18], [35], [43], [26], } \\
\text { [13], [19], [20], [46], [25], [29], [9] }\end{array}$ \\
\hline
\end{tabular}

(1) Social Exchange Theory (SET)

Social exchange explains social change and stability as a process of negotiated exchanges between parties. Social exchange theory (SET) posits that all human relationships are formed by the use of a subjective cost-benefit analysis and the comparison of alternatives [5]. According to the SET, customers perceive higher risks compared to conventional shopping environment on the Internet as a result of long distances, virtual identities, or lack of regulations [44]. Relevant to SET, Lou [30] concludes that characteristic-based trust, processbased trust and institutional-based trust are antecedents of general trust online, and that building customers' trust, a core component of SET and relationship marketing, can be one of these solutions. Trust becomes more critical than ever in the new era of Internet and web media. Kim et al. [23] utilized two important factors related to SET are time discrepancy and satisfaction to contrast consumer trust and purchase behavior between pre-purchase and post-purchase stage. Zhang and Zhang [46] adopt SET in their proceeding paper to prove trust is significant in the initial stage of transaction on Internet.

(2) Expectation-Confirmation Theory (ECT)

Expectation-confirmation theory (ECT) is proposed by Oliver [34] to widely study consumer satisfaction, repurchase intention and behavior. The underlying logic of the ECT framework is: consumers firstly form an initial expectation prior to purchase, and then engender perceptions about its performance after a period of initial consumption. Thus, they may decide the satisfaction level based on the extent to which their expectation is confirmed through assessing the perceived performance by their original expectation. Finally, the satisfied consumers form repurchasing intentions. Trust is the expectation that other individuals or companies with whom one interacts will not take over advantage of a dependence upon them [18]. Since trust involves in expecting of transaction, it must relate to ECT for deciding which store is trustworthy. Kim et al. [23] accept the trustsatisfaction relationship is developed through repeated interactions, and it is expected that trust is related to the level of satisfaction. Furthermore, a consumer's trust positively affects a consumer's expectation with an e-retailer's product or service in the research model. Zhang and Zhang [46] have also conducted the ECT in their proceeding paper for develop a model which could explain the repurchase intention as well we long term trust formation. Koppius et al. [25] integrated ECT with the TAM model, since in both models Perceived Usefulness plays a central role and thus provides a natural connection point even though trust and perceived risk played no significant role at this research.

(3) Theory of Reasoned Action (TRA)

The theory of reasoned action (TRA) originated by Fishbein and Ajzen [14] is to analyze the correlation of belief, attitude, intention and behavior. TRA has been widely applied on studying trust online. In an e- 
commerce context, attitudes regarding a vendor are formed from the perceptions of trust in the vendor. Attitudes have an effect on purchase intentions and thereby should follow the belief-attitude-intention sequence described in the TRA. Moreover, perceived trust reflects a belief system that leads to attitudes and intentions. Pennington et al. [38] tested predictive validity of the constructs in the widely accepted TRA framework. The research described below examines system trust within its nomological network of constructs, including specific trust mechanisms that can affect system trust. The model is tested under various conditions of reputation in order to demonstrate its robustness. By extrapolating from TRA, trust can be viewed as an antecedent belief (a confident expectation) that creates a positive attitude toward the transaction behavior, which in turn leads to transaction intentions. Suh and Han [43] prove that trust has a positive impact on a customer's attitude toward using ecommerce for trade transactions. Using the same logic, Mcknight et al. [33] and Pavlou [35] show that trusting beliefs in specific online vendors are correlated with transaction intentions with those same vendors. These researches find significant effect that trust in evendor positively influence attitude to purchase online. Liao et al. [29] conducted the TAM and compared with TRA in their research for develop a model. The result exhibited habitual activity with a web site will positively affect user's trust in the web retailer.

\section{(4) Theory of Planned Behavior (TPB)}

Ajzen [1] found attitude and subjective norms could not fully determine intention. He found that perceived behavioral control determine intention too. Perceived behavioral control reflects the degree that an individual feels successfully engaging is completely up to them. Thus, according to the theory of planned behavior (TPB) expanded by Ajzen [2]: a person's behavioral intention is viewed as a function of three factors: attitude towards the behavior, subjective norms, and perceived behavioral control. TPB hasn't widely been extended for model that research trust online. Li et al. [28] reviewed and compared two initial trust formation models. The first model was proposed by McKnight et al. [32]. The second model that trust was defined as a four-form composite construct, including trusting behavior, trusting intention, trusting attitude, and trusting belief, is based on the TRA and TPB. Zhang and Zhang [46] include SET, TRA, and TPB in their proceeding model. They approve TPB in their model where attitude toward trust is influenced by general trust beliefs, system trust, interaction between customer and e-vendor, and situational decision to trust.

(5) Technology Acceptance Model (TAM)

TAM [10] based on the Theory of Reasoned Action [14], suggests that users' voluntary decision to accept (i.e., use) a new Information Technology (IT) is based on their rational assessment of its expected outcomes. According to TAM, the intention to accept or use a new technology is determined by its perceived usefulness (PU) and perceived ease of use (PEOU) of the technology. In addition, PEOU primarily influences intended acceptance through its effect on PU [10]. TAM has a history of use in the eCommerce and is considered robust in a wide variety of contexts. These researches mostly fallow the logic of TAM includes the concept for their models which research trust online [21, 16, 18, 17, 26, 24, 9]. Furthermore, some of these researches extend TAM by more related constructs and more interesting issues. Gefen et al. [16] research the difference between potential and repeat customers when building trust online. Their experimental research also concludes that the PU didn't influence the purchase intentions of potential customer but PU did influence the purchase intentions of repeat customer. Gefen and Straub [18] found the PEOU and PU affect purchase intentions positively. Gefen et al. [17] develop an integrated model for purchase intention of repeat online customer. They found that there are two kinds of trust antecedents (institution-based situational normality \& knowledge-based familiarity) which positively affect PEOU. Koufaris and Hampton-Sosa [26] include TAM in their research for studying initial trust in e-commerce. They found that PU and PEOU of the web site were significant antecedents of initial trust in the company. Cyr et al. [9] used TAM and proposed a model for e-Loyalty to examine how varied conditions of social presence in a B2C e-Services context influence e-Loyalty and its antecedents of perceived usefulness, trust and enjoyment. The results show that higher perceived social presence will effect in higher levels of trust and higher levels of trust will effect in higher eLoyalty toward an e-Services website.

\section{Outcomes and Convergence Phase}

The outcome phase aims at description the research phenomenon for B2C trust based on the classification and providing with the suggestions for future research in the field. A key criticism of much of the current literature concerns the trust nature. From Figure 2 the current researches were focused on overall trust. Different phases of trust can be distinguished [40]: the phase of trust building, where 
trust is formed; the phase of stabilizing trust, where trust already exists; and the phase of dissolution, where trust declines. Only in eight of the reviewed researches the authors explicitly point to the phase of initial trust, and four researches relate to ongoing trust. It is suitable for applying three phase of building trust into commerce strategy. E-vendor attract customer via forming initial trust in the phase of trust building. E-vendor keeps customer loyalty by maintain customer trust in the phase of stabilizing trust. After that, when it goes into the phase of dissolution, trust needs to be rebuilt. The phase of dissolution that previous researchers never mention on trust building online isn't still full discussion. It may be an issue for future research. Other researches that research on ongoing trust that overlapping both overall trust and multi-dimensions, and initial trust that overlapping multi-dimensions. Hence we argue that the perspectives of ongoing trust and initial trust should be reflected in this field. Moreover, the comprehensive and the ongoing trust researches were both only three, the researchers should associate the focal point with comprehensive in the future.

In a recent paper Shankar, Urban, and Sultan [42] also have emphasized the lack of clear distinctions between the underlying dimensions and antecedents of on-line trust. They noticed that the investigated trust constructs are blurred and not well differentiated, and elements and determinants of online trust often are used interchangeably. Gefen et al. [17] identifies five trust antecedent categories that include knowledge-based trust, institution-based trust, calculative-based trust, cognition-based trust, and personality-based trust. The summary is shown in table 3. According to the research views of Gefen et al. [17], the nature of B2C trust researches should recognize more detailed, besides the oversimplification of the trust nature.

Table 3. Five trust antecedent categories from Gefen et al. (2003b)

\begin{tabular}{ll} 
Category & Trust Antecedents \\
\hline $\begin{array}{l}\text { Knowledge-based } \\
\text { trust }\end{array}$ & $\begin{array}{l}\text { Familiarity, Social presence, } \\
\text { PU, PEOU, Process-based trust, } \\
\text { Graphic design, Content design, } \\
\text { Web site appeal }\end{array}$ \\
\hline \multirow{2}{*}{$\begin{array}{l}\text { Institution-based } \\
\text { trust }\end{array}$} & $\begin{array}{l}\text { Structural Assurances, } \\
\text { trust, Trust in intermediary, } \\
\text { Privacy statements Escrow } \\
\text { service, Perceived security of } \\
\text { control, Structure design }\end{array}$ \\
\hline Calculative-based & $\begin{array}{l}\text { Perceived size, Perceived } \\
\text { reputation }\end{array}$ \\
\hline trust &
\end{tabular}

\begin{tabular}{ll} 
Category & Trust Antecedents \\
\hline Cognition-based & $\begin{array}{l}\text { Characteristic-based trust, } \\
\text { Social-cue design, Feedback } \\
\text { mechanism, Word-of-Mouth } \\
\text { Referrals }\end{array}$ \\
\hline $\begin{array}{l}\text { Personality-based } \\
\text { trust }\end{array}$ & $\begin{array}{l}\text { Disposition to trust, Situational } \\
\text { decision to trust }\end{array}$
\end{tabular}

From Table 2, SET, ECT and TPB haven't widely been extended for model that research trust online. Only in two of the reviewed researches the authors adopted TPB to develop model and accompanied the trust with model. The researches relate to SET and ECT is both three articles. Such seven articles [35, 22, 43, 46, 24, 29] used over two theories. The researchers should try to utilize the theories and associate the theories more with comprehensive in the future. The testing isn't rigorous due to the lack of theories. This does not constitute a sufficiently rigorous theory base. Hence there is a need for research theories aimed at testing current models. The future research in this area should clearly indicate how proposed models should be tested base on theory.

\section{CONCLUSION}

Customer trust can reduce perceived social complexity of an on-line transaction by allowing consumers to reduce the perceived possible opportunism of e-Vendor behaviors. This paper's primary objective was to provide an overview of empirical research on trust in electronic commerce from 2001 to 2006 to allow cumulative analysis of results. Even though this literature review can not claim to be exhaustive, it provided reasonable insights and showed the incidence of research on this subject. This paper provides a detailed table of research trends and patterns in $\mathrm{B} 2 \mathrm{C}$ trust researches. The nature of B2C trust researches can be recognized and categorized by literature review. Those include comprehensive, ongoing trust, overall trust and initial trust. It may be an issue for future research that the trust rebuilding when dissolution phase, and the nature of B2C trust researches should recognize more detailed, besides the oversimplification of the trust nature. Additionally, several theories are used in B2C trust researches, such as social exchange theory (SET), expectation-confirmation theory (ECT), theory of reasoned action (TRA), theory of planned behavior (TPB), technology acceptance model (TAM). Those trust building models are developed under the base on theories in the environment of ecommerce. Researches on trust in e-commerce mostly apply TAM and/or TRA in their search model 
between 2001 and 2006. Although SET, ECT and TPB didn't be adopted repeatedly, they are still suit for applying in model which is studying trust in ecommerce because of their definition in essence. Furthermore, this paper suggests a conceptual framework that includes three primary phases: selection and focus, analysis, and outcomes and convergence to build up the knowledge in B2C trust researches. The findings of 37 selected previous researches through the framework can help us to understand the researchable trend.

\section{REFERENCES}

1. Ajzen, I. (1985). From intentions to actions: A theory of planned behavior. In J. Kuhl and J. Beckmann (Eds), Action control: From cognition to behavior. Springer Verlag, New York, 11-39.

2. Ajzen, I. (1991). The theory of planned behavior. Organizational Behavior and Human Decision Processes, 50, 179 - 211.

3. Basso, A., Goldberg, D., Greenspan, S. \& Weimer, D. (2001) . First impressions: Emotional and cognitive factors underlying judgments of trust e-commerce. Proceedings of the 3rd ACM Conference on Electronic Commerce, 137-143.

4. Bhattacherjee, A. (2002). Individual trust in online firms: scale development and initial trust. Journal of Management Information Systems, 19(1), 213-243.

5. Blau, P. (1964). Exchange and Power in Social Life, Wiley, New York.

6. Chen, S. C. \& Dhillon, G. S. (2003). Interpreting dimensions of consumer trust in e-commerce. Information Technology and Management, (4), 303-318.

7. Cheung, C. M. K. \& Lee, M. K. O. (2001). Trust in internet shopping: A proposed model and measurement instrument, Proceedings of Americas Conference on Information Systems, 681-686.

8. Cheung, C. M. K. \& Lee, M. K. O. (2006).Understanding Consumer Trust in Internet Shopping: A Multidisciplinary Approach. Journal of the American Society for Information Science and Technology, 57(4), 479-492.

9. Cyr, D., Hassanein, K., Head, M., \& Ivanov, A. (2007). The role of social presence in establishing loyalty in e-Service environments. Interacting with Computers, 19, 43-56.

10. Davis, F. D. (1989). Perceived usefulness, perceived ease of use and user acceptance of information technology. MIS Quarterly, 13(3),
319-340.

11. De Ruyter, K., Wetzels, M., \& Kleijnen, M. (2001). Customer adoption of e-services: an experimental study. International Journal of Service Industry Management, 12(2), 184-207.

12. Eastlick, M. A., Lotz, S. L., \& Warrington, P. (2006).Understanding online B-to-C relationships: An integrated model of privacy concerns, trust, and commitment. Journal of Business Research, 59, 877-886.

13. Eriksson, K., Kerem, K., \& Nilsson, D. (2005).Customer acceptance of internet banking in Estonia. International Journal of Bank Marketing, 23(2), 200-216.

14. Fishbein, M.A. \& Ajzen, I. (1975). Belief, Attitude, Intention and Behavior: An Introduction to Theory and Research, MA: Addison-Wesley.

15. Gefen, D. (2002). Reflections on the dimensions of trust and trustworthiness among online consumers. ACM SIGMIS Database, 33(3), 3853.

16. Gefen, D., Karahanna, E., \& Straub, D. W. (2003a). Trust and Tam in online shopping: an integrated model. MIS Quarterly, 27(1), 51-90.

17. Gefen, D., Karahanna, E, \& Straub, D. W. (2003b). Inexperience and experience with online stores: The importance of TAM and Trust. IEEE Transactions on Engineering Management, 50(3), 307-321.

18. Gefen, D. \& Straub, D. (2003). Managing user trust in B2C e-services. e-Service Journal, 2(2), 7-25.

19. Hampton-Sosa, W. \& Koufaris, M. (2005). The effect of web site perceptions on initial trust in the owner company. International Journal of Electronic Commerce, 10(1), 55-83.

20. Holsapple C. W. \& Sasidharan S. (2005). The dynamics of trust in B2C e-commerce: a research model and agenda. Information Systems and EBusiness Management, 3(4), 377-403.

21. Kini, A. D. \& Choobineh, J. (2001). An empirical evaluation of the factors affecting trust in web banking system. Americas Conference on Information System 2000, 185-191.

22. Koufaris, M. \& Hampton-Sosa, W. (2002). Customer trust online: examining the role of the experience with the Web-site. CIS Working Paper Series, Zicklin School of Business, Baruch College, New York. Electronic publication.

23. Kim, D. J., Ferrin, D. L., \& Rao, H. R. (2003). A Study of the Effect of Consumer Trust on Consumer Expectations and Satisfaction: the Korean Experience. Proceedings of the 5th international conference on Electronic 
commerce, 310-315.

24. Kim, K. K. \& Prabhakar, B. (2002). Initial trust and the adoption of B2C e-commerce: the case of Internet banking. The DATA BASE for Advances in Information Systems.

25. Koppius, O., Speelman, W., Stulp, O., Verhoef, B., \& Heck, E. V. (2005). Why Are Customers Coming Back To Buy Their Airline Tickets Online? Theoretical Explanations and Empirical Evidence. Proceedings of the 7th international conference on Electronic commerce, 319-326.

26. Koufaris, M. \& Hampton-Sosa, W. (2004). The development of initial trust in an online company by new customers. Information and Management, 41(3), 377-397.

27. Lee, K. O., Matthew, \& Turban, E. (2001). A trust model for consumer Internet shopping. International Journal of Electronic Commerce, 6(1), 75 - 91.

28. Li, X., Valacich, J. S., \& Hess, T. J. (2004). Predicting user trust in information systems: A comparison of competing trust models. Proceedings of the 37th Hawaii International Conference on System Sciences.

29. Liao, C., Palvia, P., \& Lin, H. N. (2006). The roles of habit and web site quality in e-commerce. International Journal of Information Management, 26, 469-483.

30. Luo, X. (2002). Trust production and privacy concerns on the Internet: A framework based on relationship marketing and social exchange theory. Marketing Management, 31(2), 111-118.

31. McKnight, D. H., Choudhury, V., \& Kacmar, C. (2002a). Developing and validating trust measures for e-commerce: An integrative typology. Information Systems Research, 13(3), 34-59.

32. McKnight, D. H., Choudhury, V., \& Kacmar, C. (2002b). The impact of initial consumer trust on intentions to transact with a web site: a trust building model. Journal of Strategic Information Systems, 11, 297-323.

33. Mcknight, D. H., Kacmar, C. J., \& Choudhury, V. (2004). Shifting factors and the ineffectiveness of third party assurance seals: A two-stage model of initial trust in a web business. Electronic Markets, 14(3), 252-266.

34. Oliver, R. L. (1980). A cognitive model of the antecedents and consequences of satisfaction decisions, Journal of Marketing Research, 17, 460-469.

35. Pavlou, P. A. (2003). Consumer acceptance of electronic commerce-integrating trust and risk with the technology acceptance model. International Journal of Electronic Commerce,
7(3), 69-103.

36. Pavlou, P.A. \& Chellappa, R. K. (2001). The role of perceived privacy and perceived security in the development of trust in electronic commerce transactions. Special Issue of ISR on Electronic Commerce Metrics.

37. Pavlou, P. A. \& Gefen D. (2004). Building effective online marketplaces with institutionbased trust. Information Systems Research, 15(1), 37-59.

38. Pennington, R., Wilcox, H. D., \& Grover, V. (2003). The role of system trust in business-toconsumer transactions. Journal of Management Information Systems, 20(3), 197-226.

39. Resnick, P. \& Zeckhauser, R. (2002). Trust among strangers in Internet transactions: Empirical analysis of eBay's reputation system. Advances in Applied Microeconomics, (11).

40. Riegelsberger, J., Sasse, M.A., \& McCarthy, J. D. (2003). Shiny happy people building trust? : Photos on e-commerce websites and consumer trust. Proceedings of the SIGCHI conference on Human factors in computing systems, April 0510, Ft. Lauderdale, Florida, USA.

41. Rousseau, D. M., Sitkin, S. B., Butt, R. S., \& Camerer, C. (1998). Not so different after all: a cross-discipline view of trust. Academy of Management Review, 23(3), 393-404.

42. Shankar, V., Urban, G. L., \& Sultan, F. (2002). Online trust: a stakeholder perspective, concepts, implications, and future directions. Journal of Strategic Information Systems, 11(3), 325-344.

43. Suh, B. \& Han, I. (2003). The impact of customer trust and perception of security control on the acceptance of electronic commerce. International Journal of Electronic Commerce, 7(3), 135-161.

44. Wang, Y. D. \& Emurian, H. H. (2005). An overview of online trust: concepts, elements, and implications. Computers in Human Behavior, 21, 105-125.

45. Yousafzai, S.Y., Pallister, J. G., \& Foxall, G. R. (2005). Strategies for Building and Communicating Trust in Electronic Banking: A Field Experiment. Psychology \& Marketing, 22(2), 181-201.

46. Zhang, X., \& Zhang, Q. (2005). Online trust forming mechanism: approaches and an integrated model. Proceedings of the Seventh International Conference on Electronic Commerce, 201-209. 